\title{
Kadın Konukevlerinde Kalan Çocukların Problem Davranışları Üzerinde Oyun Terapisinin Etkisinin İncelenmesi
}

\author{
Fatma Elif Kılınç'®i), Nalan Saltıkº
}

${ }^{1}$ Ankara Yıldırım Beyazıt Üniversitesi, Sağlık Bilimleri Fakültesi, Çocuk Gelişimi Bölümü, Ankara, Türkiye ${ }^{2}$ Çekirdek Oluş Güvenli Bağlanma Merkezi Batıkent Şubesi, Ankara, Türkiye

Fatma Elif Kılınç, Doç. Dr. Nalan Saltık, Bilim Uzmanı

Iletişim:

Doç. Dr. Fatma Elif Kılınç Ankara Yııdırım Beyazıt Üniversitesi, Sağlık Bilimleri Fakültesi, Çocuk Gelişimi Bölümü, Ankara, Türkiye Tel: +903129061924

E-Posta: fekilinc@ybu.edu.tr

Gönderilme Tarihi : 27 Mayıs 2018 Revizyon Tarihi : 21 Haziran 2018 Kabul Tarihi : : 26 Haziran 2018

\section{ÖZET}

Amaç: Araştırmada çeşitli travmatik durumlara maruz kalan kadın konuk evlerindeki üç-altı yaş grubu çocukların problem davranışları üzerinde oyun terapisinin etkisinin olup olmadığııı belirlemek amaçlanmıştır.

Hastalar ve Yöntem: Araştırma deney-kontrol gruplu, ön-test, son-test ve izleme ölçümlerinin yapııldığı deneysel bir çalışma olup, kadın konukevlerinde anneleri ile birlikte kalan 3-6 yaşlarında 4 deney grubunda, 4 kontrol grubunda olmak üzere toplam 8 çocukla gerçekleştirilmiştir.

Bulgular: Araştırmada veriler; “Ebeveyn-Çocuk Bilgi Formu” ve “Okul Öncesi ve Anaokulu Davranış Ölçeği (PKBS-2)” ile toplanmıştır. Deney grubundaki çocuklara her biri 30 dakika süren, 14 oturumdan oluşan oyun terapisi uygulanmıştır. Analizler nonparametrik olarak IBM SPSS 21 paket programı ile değerlendirilmiştir. Deney ve kontrol gruplarının ön test ve son test ortalamalarını karşılaştırmak için Mann-Whitney U-testi, deney ve kontrol gruplarında ön test, son test ve izleme testi ortalamalarııı karşılaştırmak için Wilcoxon İşaretli Sıralar Testi kullanıımıștır. Araştırmanın bulgularından elde edilen sonuçlar, deney grubundaki çocukların içe yönelim ve dışa yönelim davranış problemlerinin azaldığını göstermektedir.

Sonuç: Araştırmada oyun terapisine katılan çocukların dışa vurulan saldırgan ve düşüncesiz aşırı hareketli davranışları ile korku, endişe, çekingenlik gibi içsel duygularına yönelik problem davranışlarının azaldığı belirlenmiştir.

Anahtar sözcükler: Kadın konukevlerindeki çocuklar, oyun terapisi, problem davranış

\section{EXAMINATION OF THE EFFECTS OF PLAY THERAPY ON PROBLEM BEHAVIORS OF CHILDREN IN WOMEN'S SHELTER HOMES}

\section{ABSTRACT}

Purpose: The purpose of the study was to determine whether the play therapy had an effect on the problem behaviors in children aged three-six years in women's shelter homes exposed to various traumatic situations in the study.

Patients and Methods: The study was an experimental study in which experimental-control group, pre-test, post-test and follow-up measurements were made and it was carried out with 8 children aged 3-6 years in 4 experimental groups and 4 control groups in women's shelter homes with their mothers.

Results: It is given in the research; "Parent-Child Information Form "and "Preschool and Kindergarten Behavior Scales (PKBS-2)". Children in the experimental group were given a 14-session game therapy, each of which lasted 30 minutes. Analyzes were evaluated non-parametrically with the IBM SPSS 21 package program. The Mann-Whitney U-test was used to compare the pretest and post-test averages of the experimental and control groups, and the Wilcoxon signed-rank test was used to compare the pre-test, post-test, and follow-up test averages of the experimental and control groups. The results of the study show that of the children in the experimental group are increased?!?!, and inward and outward behavior problems are decreased. (The results of the study show that the inward and outward behavior problems of children in the experimental group decreased)

Conclusion: In the study, it was determined that the children who participated in the play therapy had aggressive and inconsiderate hyperactive behaviors that were shot outside?!?! (acted out) and problem behaviors related to inner feelings such as fear, anxiety, and hesitancy decreased.

Keywords: Children in women's shelter homes, play therapy, problem behavior 
rken çocukluk dönemi gelişimin temellerinin atıldığı, temel bilgi ve becerilerin kazanıldığı yıllar olması ve diğer yaşam dönemleri ile kıyaslandığında gelişim alanlarının birbiriyle ilişkisinin en fazla olduğu dönem olması nedeniyle kritik yıllar olarak adlandırılmaktadır (1). Bu dönemde bilişsel, dil, sosyal-duygusal, psiko-motor gelişim alanları yönünden çocuğun hızlı bir gelişim göstermesi ve özbakım becerilerini kazanması nedeniyle eğitime doğum ile başlanmaktadır $(2,3)$. Bu yıllarda gelişimsel olarak görülen özelliklerin, istenmeyen davranışlar haline gelmemesi ve ileride sağlıkı bir ruh haline sahip olabilmesi açısından erken müdahale önem arz etmektedir. Özellikle erken çocukluk döneminde sıklıkla görülen uyum ve davranış bozuklukları doğru bir müdahale ile belirlenerek çözüm için gerekli önlemler alınmazsa çocukların sonraki yaşamında sosyal-duygusal açıdan problem yaşama ve sosyal uyumsuzluk gösterme ihtimalinin yüksek olduğunu bilinmektedir (4-6).

Davranış problemleri bireyin gözlenebilen ya da ölçülebilen davranışlarında meydana gelen uyum problemleridir. Çocuğun yaşına uygun değer ve kurallara uyumsuzluk, başkalarının hakkına saygı göstermeme, saldırganlık, yalan söyleme, düşük akademik performans gibi davranışlar problem davranışlara örnek olarak gösterilebilir (7). Çocukları anlamanın ve onlarla iletişim kurmanın en doğal ve sağlıklı yolu olan oyun çocuğun hayatında kritik bir öneme sahiptir. Oyunun tipik gelişim gösteren çocukların gelişimini desteklemesinin yanında pek çok terapötik gücü de bulunmaktadır $(8,9)$. Oyun terapisi ise bu tür davranış bozukluğu olan çocuklara sağladığı ortam ile çocukların kendilerini tanımasını sağlamakta, onları oldukları gibi kabul ederek terapi boyunca olgunlaşmalarında büyük faydalar sağlamaktadır (10).

Çocuklar kendi dünyasında olup bitenleri oyunlarına yansıtırlar. Özellikle duygusal yönden zarar verici yaşantılarını sembolik olarak canlandırarak kişisel deneyimlerini özümser ve çevresel baskıları görmezden gelir. Landreth'in tespitiyle oyun terapisinde oyun çocuğun dili oyuncaklar ise kelimeleridir. Oyun terapisi, oyun esnasında çocuklara iç dünyalarını yansıtma imkanı verdiği için, yetişkinlerin psikolojik danışmanlık almaları gibi çocuklar için de psikoterapi niteliğindedir. Çocuklar oyunlardaki sembolik yansımalar sayesinde duygusal deneyimlerini serbest bir biçimde kendilerini ifade etmesini sağlamaktadır (11-14). Baggerly, Ray ve Bratton (2010)'a göre oyun terapisi; davranış problemleri, saldırganlık, kaygı ve depresyon, sosyal problemler ve stres düzeylerini azaltmada olumlu etkileri bulunmaktadır (15).
Aile ve Sosyal Politikalar Bakanlığı, Türkiye'de Kadına Yönelik Aile İçi Şiddet Araştırması (2008) araştırma sonuçlarına göre annenin şiddet yaşama durumuna göre çocuklarda görülen bazı davranış bozuklukları incelendiğinde annenin şiddet yaşamadığı durumda; sık sık kabus görme $\% 20$, yatağını ıslatma $\% 18$, çekingen/içine kapanık olma \%43, anneye/diğer çocuklara karşı saldırgan olma \%20, hırçınlaşarak ağlama durumu \%36'dır. Annenin şiddet yaşadığı durumlarda ise; sık sık kabus görme \%33, yatağını ıslatma \%28, çekingen/içine kapanık olma \%56, anneye/diğer çocuklara karşı saldırgan olma \%38, hırçınlaşarak ağlama durumu \%59'dur (16). Bu oranlara bakıldığında çocukların sağlıklı gelişim göstermeleri adına şiddet mağduru kadınların çocuklarının ruh sağlığı üzerinde durulması gereken bir konu olarak karşımıza çıkmaktadır.

Kadın ve çocukların maruz kaldıkları olumsuz durumlar özellikle şiddet, ömür boyu silinmez yaralar açmaktadır. Şiddet mağduru kadınların bulunduğu kadın konuk evlerinde, kendileri ve çocukları için fiziksel korunmanın yanı sıra sosyal ortama geri döndüklerinde uyum adına destek ve güçlendirme programları yer almaktadır. Bu programlarda, yaşadıkları durum karşısında alternatif çözüm yolları hakkında bilgi verilerek maruz kaldıkları şiddetten dolayı meydana gelen endişe, korku gibi davranışları ortadan kaldırmaya yönelik çalışmalar bulunmakta fakat çocuklara yönelik programlar yeterli olmamaktadır $(17,18)$. Bu bağlamda kadın konukevlerinde anneleri ile birlikte çocuklar ayrıca ele alınması gerekmektedir.

\section{Yöntem}

\section{Araştırmanın modeli}

Bu araştırma, kadın konukevlerinde kalan çocuklarda oyun terapisinin problem davranışlarına etkisinin ilişkisel olarak incelendiği ön-test, son-test ve izleme ölçümlü deneysel bir çalışmadır (19). Araştırmada oyunun sağaltıcı özelliğini kullanarak çocuğun gelişimini takip etme, psikolojisini tanıma ve gerektiği durumlarda müdahale etmek için kullanılan yöntemlerden biri olan oyun terapisi kullanılmıştır. Çalışmada araştırmacılardan biri "Psikolojik Testler Derneği"nden oyun terapisi sertifikasını almıştır. Bu doğrultuda 14 seanslık yönlendirici olmayan oyun terapisi uygulanması planlanmıştır. Yönlendirmesiz oyun terapisi; çocuk kendi adımlarıyla duygusal sorunlarını çözmeye çalışırken kullandığı oyun ve dili terapist tarafından dinlenip anlayarak çocuğa yanıt vermesidir. Uygulamanın ilk oturumları tanışma içerikli olarak başlamış ilerleyen oturumlar standartlara uygun şekilde devam etmiştir. 


\section{Çalışma grubu}

Araştırmanın çalışma grubunu Aile ve Sosyal Politikalar Bakanlığı'na bağlı bir ilde yer alan üç kadın konukevinde 36-72 aylık çocuğu olan ve araştırmaya katılmayı kabul eden anneler ve çocukları oluşturmuştur. Araştırma yapılan kadın konukevlerinin bulunduğu il, anneler ve çocukların bilgileri güvenlik nedeniyle belirtilmemektedir. Araştırmaya dahil edilen deney grubundaki çocukların \%75'i kız, \%25'i erkek; kontrol grubundaki çocukların ise $\% 25$ 'i kız, \%75'i erkektir. Deney grubundaki çocukların 1'i 44 ay, 1'i 46 ay, 1'i 50 ay ve 1'i de 62 aylık olup, kontrol grubundaki çocukların 1'i 39 ay, 1'i 41 ay, 1'i 46 ay ve 1'i de 55 aylıktır. Kardeş sayılarına bakıldığında deney grubundaki çocukların \%25'i tek çocuk, \%75'i 2 kardeş; kontrol grubundaki çocukların yarısı tek çocuk yarısı da iki kardeş olarak belirlenmiştir.

\section{Deney grubu}

Aile ve Sosyal Politikalar Bakanlığı tarafından belirlenen bir ildeki kadın konukevlerinde çalışmaya başlamadan önce, araştırmanın kapsamındaki 36-72 aylık çocuklar kurum yetkililerince belirlenmiştir. A kodlu konuk evinde 36-72 aylık sekiz çocuk anneleri ile birlikte kalmaktadırlar. Çocuk gelişim uzmanı ve sosyal hizmet uzmanları rehberliğinde araştırmacı tarafından anneler ile bireysel görüşmeler gerçekleştirilmiş ve çalışmanın kapsamı açıklanmıştır. Annelere, çalışmaya katılımın gönüllülük esasına bağı olacağı ve kişisel bilgilerin kesinlikle gizli tutulacağı özellikle belirtilmiştir. Görüşmeler sonrasında A kodlu kadın konukevindeki annelerden birinin başka bir ile nakil istemesi, birinin çalışmaya katılmak istememesi, bir annenin de yabancı uyruklu olduğundan dil problemi sebebiyle araştırma grubuna dâhil olmamışlardır. Alınan bilgiler doğrultusunda deney grubu olarak 36-72 aylık (A) kodlu kadın konukevinde kalan dört çocukla annelerinin izinleri dâhilinde çalışılmıştır.

\section{Kontrol grubu}

Araştırmanın kontrol grubunu, uygun görülen ve tez çalışmasında (B) kodlu konukevi olarak belirtilen kadın konukevinde, annesi ile birlikte kalan 36-72 aylık çocuklar oluşturmaktadır. Araştırma kapsamındaki çocuklar kadın konukevi yetkililerince tespit edilmiştir. Çocuklar çalışmaya dâhil edilirken yaş ve sosyal yaşantı düzeyleri göz önünde bulundurulmuş ve deney grubunda mevcut yaşlara karşılık gelmesine dikkat edilmiştir. Çocuk gelişim uzmanı ve sosyal hizmet uzmanı rehberliğinde çalışmaya katılacak anneler ile bireysel görüşmeler gerçekleştirilmiş ve araştırmaya katılımın gönüllülüğü ve kişisel bilgilerin gizli tutulacağı ile ilgili bilgilendirmeler yapılmıştır. Yapılan görüşmeler sonrasında dört anne araştırmaya, kontrol grubu olarak katılmayı kabul etmişlerdir.

\section{Veri toplama araçları}

Araştırmada veriler, araştırmacı tarafından geliştirilen Ebeveyn/Çocuk Bilgi Formu ve "Okulöncesi ve Anaokulu Davranış Ölçeği" aracılığıyla toplanmıştır.

\section{Ebeveyn-Çocuk Bilgi Formu}

Araştırmacı tarafından hazırlanan "Ebeveyn Bilgi Formu" iki bölümden oluşmaktadır. İlk bölümde çocuğun doğumu, bakımı, geçirdiği hastalıklar gibi çocuğa ait bilgiler sorulurken, ikinci bölümde ise ebeveynlerin yaşları, çalışma ve eğitim durumları gibi anne ve babaya ait sorular yer almaktadır. Bilgi formu, araştırmaya dahil edilen çocukların anneleri tarafından araştırmacı rehberliğinde kurumun çocuk gelişim uzmanı ile birlikte doldurulmuştur.

\section{Okul Öncesi ve Anaokulu Davranış Ölçeği (PKBS-2)}

Okul Öncesi ve Anaokulu Davranış Ölçeği; sosyal beceri ölçeği ve problem davranış ölçeği olmak üzere iki bölümden oluşmaktadır. Bu çalışmada problem davranış ölçeği kullanılmıştır. Okul Öncesi ve Anaokulu Davranış Ölçeği Kenneth W. Merrell tarafından 1994 yılında geliştirilmiş ve 2003 yılında ölçek tekrar gözden geçirilerek norm çalışması yapılmıştır. Ölçeğin Türkçeye uyarlaması için geçerlilik ve güvenirlik çalışması birçok araştırmacı tarafından yapılmıştır (20). 2008 yılında Okyay, 2009 Alisinanoğlu ve Özbey tarafından Okul Öncesi ve Anasınıfı Davranış Ölçeği olarak geçerlik güvenirlik çalışması gerçekleştirilmiştir $(21,22)$. 2011 yılında ise Fazlıoğlu ve diğ. tarafından geçerlilik ve güvenirlik çalışması tekrarlanmıştır. 2014 yılında Mehmetali, Batı Trakya örnekleminde okul öncesi ve anaokulu davranış ölçeğinin geçerlilik ve güvenirlik çalışmasını yapmış Türk kültürüne uygun olduğu sonucuna ulaşılmıştır (23). Problem Davranış Ölçeğinin alpha katsayıları 0,75 ve 0,90 aralığında olduğu belirtilmiştir. Araştırma kapsamında gerçekleştirilen güvenirlik katsayıları incelendiğine; Problem Davranış Ölçeğinin Cronbach alpha katsayıları 0,59 ve 0,69 aralığında olup PDÖ alt boyutları için hesapIanan Cronbach alpha katsayıları; Problem Davranış Ölçeği toplam puanı 0,59, DY 0,69, iY 0,64 olarak bulunmuştur.

\section{Verilerin toplanması}

Verilerin toplanması için öncelikle Ankara Yıldırım Beyazıt Üniversitesi Sosyal ve Beşeri Bilimler Etik Kurulundan onay alındıktan sonra belirlenen kadın konukevleri için Bakanlıktan araştırma izni alınmıştır. Annelere araştırma hakkında bilgi verilmiş, çocukları ile birlikte araştırmaya katılmayı kabul ettiklerini ifade ettikten sonra çalışma 
başlamıştır. Verilerin toplanmasında mevcut araştırma kapsamında kullanılan Ebeveyn-Çocuk Bilgi Formu ile Okul Öncesi ve Anaokulu Davranış Ölçeği anneler tarafından kurumun çocuk gelişim uzmanı eşliğinde doldurulmuştur. Ölçek formunu doldurulmadan önce araştırmanın amacı hakkında kısa bir bilgi verilip annelerle bireysel görüşme yapıldıktan sonra ölçeklerle ilgili yönerge okunarak nasıl cevaplamaları gerektiği açıklanmıştır.

\section{Verilerin analizi}

Verilerin değerlendirilmesinde istatistiksel paket program olan SPSS Statistic 21.0 programından yararlanılmıştır. Deney ve kontrol grubundaki çocukların Okul Öncesi ve Anaokulu Davranış Ölçeği Problem Davranış alt boyutunda Shapiro-Wilk Testi sonucunda yapılan ön test, son test ve izleme testinden aldıkları puanların normal dağılım göstermediği belirlenmiş (Tablo 1) ayrıca örneklem büyüklüğünün 30'dan küçük olması nedeniyle gruplar arası ve gruplar içi farklar için parametrik olmayan istatistikler kullanılmıştır. Parametrik test varsayımları sağlanmadığında karşılaştırılacak grup sayısı iki olduğunda gruplar arası farkları belirlemek için Mann-Whitney U testi yapılmakta, karşılaştırılacak grup sayısı üç ve daha fazla olduğunda ise gruplar arası farkları belirlemek için Kruskal Wallis testi, gruplar içi farklar için de Wilcoxon uyumlu çiftler testi kullanılmaktadır (24). Araştırmada Deney ve Kontrol grupları arası farkların analizinde Mann-Whitney $U$ testi ve ön test-son test arasındaki farklılıkların analizinde Wilcoxon uyumlu çiftler testi kullanılmıştır.

\section{Bulgular}

Kadın konuk evlerinde anneleri ile birlikte kalan üç-altı yaş grubu çocuklarda oyun terapisinin problem davranışlara etkisinin olup olmadığını belirlemek amacıyla gerçekleştirilen araştırmaya dahil edilen anne ve çocuklarla yapılan ön görüşmede bu annelerin çocuk ile ilgili verdikleri bilgiler çerçevesinde deney grubunda bulunan annelerin $\% 100$ 'ü, kontrol grubundaki annelerin \%75'i eşinden şiddet gördügünü belirtmişlerdir. Şiddet ortamında bulunan çocuklara uygulanan ölçme aracından alınan puan ortalamaları incelendiğinde (Tablo 2) deney ve kontrol grubundaki çocukların Problem Davranış Ölçeği Dışa Yönelim Problemi $(U=6,00, p>0,05)$, İçe Yönelim $(U=7,00$, $p>0,05)$, Davranış Problemleri Ölçeği Toplam $(U=4,50$, $p>0,05$ ) alt boyutlarına ilişkin ön test puan ortalamaları arasında anlamlı bir fark olmadığı belirlenmiştir. Bu sonuca göre, eğitime başlarken deney ve kontrol grubundaki

Tablo 1. Deney ve kontrol grubundaki çocukların problem davranış alt ölçeği puanlarına ait betimsel istatistikler ve normallik testi sonuçlanı

\begin{tabular}{|c|c|c|c|c|c|c|c|}
\hline \multicolumn{2}{|c|}{$\begin{array}{l}\text { Problem Davranıs Ölçeği } \\
N=8\end{array}$} & \multicolumn{3}{|c|}{$\begin{array}{c}\text { Deney } \\
n=4\end{array}$} & \multicolumn{3}{|c|}{$\begin{array}{c}\text { Kontrol } \\
n=4\end{array}$} \\
\hline & & & $S$ & Shapiro-Wilk & & $S$ & Shapiro-Wilk \\
\hline & Dışa Yönelim (DY) & 28,66 & 8,50 & 0,935 & 36,25 & 14,24 & 0,769 \\
\hline \multirow[t]{3}{*}{ Ön test } & İçe Yönelim (IYY) & 20,00 & 6,24 & 0,463 & 18,50 & 7,23 & 0,992 \\
\hline & Davranış Problemleri Ölçeği Toplam & 48,66 & 11,84 & 0,081 & 54,75 & 11,81 & 0,279 \\
\hline & Dışa Yönelim (DY) & 14,00 & 2,00 & 1,00 & 37,50 & 12,47 & 0,841 \\
\hline \multirow[t]{3}{*}{ Son test } & İçe Yönelim (IYY) & 9,00 & 2,64 & 0,363 & 13,25 & 12,47 & 0,103 \\
\hline & Davranış Problemleri Ölçeği Toplam & 23,00 & 1,00 & 1,000 & 50,75 & 12,52 & 0,524 \\
\hline & Dışa Yönelim (DY) & 18,66 & 9,50 & 0,942 & & & \\
\hline \multirow[t]{2}{*}{ İzleme } & İçe Yönelim (iY) & 13,33 & 7,37 & 0,391 & & & \\
\hline & Davranış Problemleri Ölçeği Toplam & 32,00 & 15,87 & 0,363 & & & \\
\hline
\end{tabular}

Tablo 2. Deney ve kontrol grubundaki çocukların problem davranış ölçeği alt boyutlarına ilişkin ön test puanlarına ait U-testi sonuçları

\begin{tabular}{lcccccc}
$\begin{array}{l}\text { Problem Davranı̧̧ Ölçeği } \\
N=8\end{array}$ & \multicolumn{2}{c}{$\begin{array}{c}\text { Deney } \\
n=4\end{array}$} & \multicolumn{2}{c}{$\begin{array}{c}\text { Kontrol } \\
\boldsymbol{n}=\mathbf{4}\end{array}$} \\
\hline & Sıra Ort. & Sıra Toplamı & Sıra Ort. & Sıra Toplamı & $\boldsymbol{U}$ & $\boldsymbol{p}$ \\
\hline Dişa Yönelim (DY) & 4,00 & 16,00 & 5,00 & 20,00 & 6,00 & 0,56 \\
İçe Yönelim (IYY) & 4,75 & 19,00 & 4,25 & 17,00 & 7,00 & 0,77 \\
Davranış Problemleri Ölçeği Toplam & 3,63 & 14,50 & 5,38 & 21,50 & 4,50 & 0,30
\end{tabular}


çocukların davranış problemleri yönünden benzer özelliklere sahip olduğu söylenebilir. Bu sonuç aynı zamanda deney ve kontrol gruplarının aynı evrenden çekildiğini göstermektedir.

Deney ve kontrol grubundaki çocukların son test puan ortalamaları arasındaki farklar incelendiğinde (Tablo 3) deney grubundaki çocukların problem davranış ölçeği dışa yönelim alt boyutu son test sıra ortalaması 2,50 , kontrol grubunda son test sıra ortalama puanının 6,50 olduğu belirlenmiştir. Yapılan Mann-Whitney $U$ testi sonuçlarına göre, deney ve kontrol grubundaki çocukların Dışa Yönelim alt boyutuna ilişkin son test puan ortalamaları arasındaki farklılığın anlamlı olduğu görülmüştür $(U=00,00$, $p<0,05)$. Deney grubundaki çocukların İçe Yönelim alt boyutu son test sıra ortalaması 2,88, kontrol grubunda son test sıra ortalama puanının 6,13 olduğu belirlenmiştir. Mann-Whitney $U$ testi sonuçlarına göre, deney ve kontrol grubundaki çocukların İçe Yönelim alt boyutuna ilişkin son test puan ortalamaları arasındaki farklılığın anlamlı olmadığı görülmüştür $(U=1,50, p>0,05)$. Deney grubundaki çocukların Davranış Problemleri Ölçeği Toplam puanı son test sıra ortalaması 2,50, kontrol grubunda son test sıra ortalama puanının 6,50 olduğu belirlenmiştir. MannWhitney U testi sonuçlarına göre, deney ve kontrol grubundaki çocukların Davranış Problemleri Ölçeği Toplam puanına ilişkin son test puan ortalamaları arasındaki farklılığın anlamlı olduğu görülmüştür $(U=0,00, p<0,05)$.

Problem davranış ölçeği alt boyutlarına ilişkin ön test, son test puanlarına ilişkin sonuçlar Tablo 4'de verilmiştir. Tablo incelendiğinde çocukların deney öncesi ve deney sonrası problem davranış ölçeği dışa yönelim alt boyutu puanları arasında anlamlı bir fark olmadığı görülmektedir $(z=1,82$, $p>0,05$ ). Ancak deney grubuna dâhil edilen çocukların ortalamalarının son test puanlarında düşüş görülmektedir. Bu düşüşün nedeni olarak verilen eğitimin problem davranışı azalttığı söylenilebilir. Deney öncesi ve deney sonrası çocukların içe yönelim alt boyutu puanları arasında anlamlı bir fark olmadığı görülmektedir $(z=1,84, p>0,05)$. Kontrol grubuna dâhil edilen çocukların deney öncesi ve deney sonrası içe yönelim puanlarında yakın bir sonuç gözlenirken, deney grubundaki çocukların son test puanlarındaki düşüş eğitimin korku, endişe, çekingenlik gibi davranışları azaltması şeklinde yorumlanabilir.

Deney öncesi ve deney sonrası çocukların Davranış Problemleri Ölçeği Toplam puanları arasında da anlamlı bir fark olmadığı görülmektedir $(z=1,82, p>0,05)$. Ancak deney grubuna dâhil edilen çocukların ortalama puanlarındaki düşüşün nedeni olarak verilen eğitimin pozitif bir etki oluşturduğu düşünülmektedir.

Tablo 3. Deney ve kontrol grubundaki çocukların problem davranış ölçeği alt boyutlarına ilişkin son test puanlarına ait U-testi sonuçları

\begin{tabular}{lcccccc}
$\begin{array}{l}\text { Problem Davranıs Ölçeği } \\
\text { N=8 }\end{array}$ & \multicolumn{2}{c}{$\begin{array}{c}\text { Deney } \\
n=4\end{array}$} & \multicolumn{2}{c}{$\begin{array}{c}\text { Kontrol } \\
n=4\end{array}$} \\
\hline & Sıra Ort. & Sıra Toplamı & Sıra Ort. & Sıra Toplamı & U & p \\
\hline Dışa Yönelim (DY) & 2,50 & 10,00 & 6,50 & 26,00 & 0,00 & $0,02^{*}$ \\
İçe Yönelim (IYY) & 2,88 & 11,50 & 6,13 & 24,50 & 1,50 & 0,05 \\
Davranış Problemleri Ölçeği Toplam & 2,50 & 10,00 & 6,50 & 26,00 & 0,00 & $0,02^{*}$ \\
\hline * $>0,05$ & & & & & &
\end{tabular}

Tablo 4. Deney ve kontrol grubundaki çocukların problem davranış ölçeği alt boyutlarına ilişkin ön test, son test puanlarına ait Wilcoxon işaretli sıralar testi sonuçları

\begin{tabular}{|c|c|c|c|c|c|c|c|}
\hline \multicolumn{2}{|c|}{$\begin{array}{l}\text { Problem Davranış Ölçeği } \\
N=8\end{array}$} & \multicolumn{2}{|c|}{$\begin{array}{c}\text { Ön test } \\
n=4\end{array}$} & \multicolumn{2}{|c|}{$\begin{array}{c}\text { Son test } \\
n=4\end{array}$} & \multicolumn{2}{|c|}{$\begin{array}{l}\text { Wilcoxon } \\
\text { Sonuçları }\end{array}$} \\
\hline & & & $s$ & & $S$ & $Z$ & $P$ \\
\hline \multirow{2}{*}{ Dışa Yönelim (DY) } & Deney & 29,75 & 7,27 & 13,75 & 1,70 & $-1,82$ & 0,06 \\
\hline & Kontrol & 36,25 & 14,24 & 37,50 & 12,47 & 0,00 & 1,00 \\
\hline \multirow{2}{*}{ İçe Yönelim (IYY) } & Deney & 20,25 & 5,12 & 7,75 & 3,30 & $-1,84$ & 0,06 \\
\hline & Kontrol & 18,50 & 7,23 & 13,25 & 2,21 & $-1,09$ & 0,27 \\
\hline \multirow{2}{*}{$\begin{array}{l}\text { Davranış Problemleri } \\
\text { Ölçeği Toplam }\end{array}$} & Deney & 50,00 & 10,03 & 21,50 & 3,10 & $-1,82$ & 0,06 \\
\hline & Kontrol & 54,75 & 11,81 & 50,75 & 12,52 & $-0,73$ & 0,46 \\
\hline
\end{tabular}


Deney grubundaki çocukların problem davranış ölçeği alt boyutlarına ilişkin son test, izleme testi puanları incelendiğinde (Tablo 5) deney grubuna katılan çocukların problem davranış ölçeği dışa yönelim alt boyutu $(z=1,06$, $p>0,05)$, içe yönelim alt boyutu, $(z=1,06, p>0,05)$, ve toplam $(z=1,06, p>0,05)$ son test ve izleme test puanlarında fark olmadığı ve puan ortalamalarının birbirine çok yakın olduğu görülmektedir. Buna göre son test ile izleme testi arasında geçen üç haftalık süre içerisinde deney gruplarındaki çocukların problem davranış ölçeği alt boyut ve toplam puanları açısından uygulanan eğitim programının kalıcılığının devam ettiği görülmektedir.

Deney ve kontrol grubunun uygulama öncesi ve sonrasında dışa yönelim ve içe yönelim alt boyutlarına ilişkin erişi puan ortalamalarının anlamlı bir fark gösterdiği belirlenmiştir (Tablo 6). Dışa yönelim erişi puanı deney grubunda 6,50 iken, kontrol grubunda 2,50 olup puan farkları arasında anlamlı bir fark görülmektedir $(U=00,00, p<0,05)$. Deney grubunda içe yönelim erişi puanı 3,25 , kontrol grubunda ise 5,75 olarak saptanmıştır. Aralarında anlamlı bir fark puanı bulunmaktadır $(U=00,00, p<0,05)$. Deney grubunda problem davranış toplam erişi puanı 3,00, kontrol grubunda ise 6,00 olarak saptanmıştır, ancak aralarında anlamlı bir ilişki görülmemiştir ( $U=00,00, p>0,05)$.

\section{Tartışma}

Kadın konukevinde anneleri ile birlikte kalan çocukların oyun terapisi aracılığıyla dışa vurulan saldırgan ve düşüncesiz aşırı hareketli davranışları ifade eden dışa yönelim problem davranışları ile korku, endişe, çekingenlik gibi içsel duyguları içeren içe yönelim problem davranışlarında azalma olduğu belirlenmiştir. Deney öncesi ve deney sonrası çocukların davranış problemleri ölçeği toplam puanları arasında anlamlı bir fark olmadığı görülmektedir. Ancak deney grubunda yer alan çocukların oyun terapisi sonrası kontrol grubunda bulunan çocuklara oranla davranış problemlerinde ivmeli düşüş (ön test: $\bar{x}=50,00$, son test: $\bar{x}=21,50$ ) olduğu görülmüştür. $B u$ sonuç Teber (2015) tarafından yapılan oyun terapisinin çocukların davranış problemleri ve psikolojik problemleri üzerindeki etkisinin sonuçları ile örtüşmektedir (25). Dışa yönelim alt boyutu deney ve kontrol grubunda bulunan çocukların son test puan ortalamaları arasındaki farklılığın anlamlı olması, deney grubundaki çocukların son test puanlarındaki düşüş, saldırganlık gibi dışa vurulan problem davranışlarında azalma olduğunu göstermektedir. Ancak deney ve kontrol grubu ön test son test aritmetik ortalamaları arasında anlamlı bir fark bulunmamıştır. Bu sonuç LeBlanc ve Ritchie'nin araştırmasında ortaya koydukları, aile katılımı ve seans süresinin uzun olmasının oyun terapisinin etkisini arttırdığı (26) bulgusu doğrultusunda araştırma sonuçlarının da bu iki faktörden etkilendiği sonucunu düşündürmektedir. Landreth ve arkadaşlarının araştırmalarında deney grubundaki çocukların içe yönelim, dışa yönelim ve davranış problemleri toplam puanlarında belirgin düşüş sağlandığını ortaya koymuşlardır. Bu sonuç aile içi şiddetin mağdurları çocukların tedavisinde yoğun bir şekilde oyun

Tablo 5. Deney grubundaki çocukların problem davranış ölçeği alt boyutlarına ilişkin son test, izleme testi puanlarına ait Wilcoxon işaretli sıralar testi sonuçları

\begin{tabular}{|c|c|c|c|c|c|c|}
\hline \multirow[t]{2}{*}{$\begin{array}{l}\text { Problem Davranış Ölçeği } \\
N=8\end{array}$} & \multicolumn{3}{|c|}{$\begin{array}{c}\text { Son test } \\
n=4\end{array}$} & \multirow{2}{*}{ 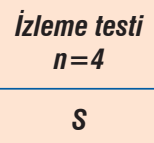 } & \multicolumn{2}{|c|}{$\begin{array}{l}\text { Wilcoxon } \\
\text { Sonuçları }\end{array}$} \\
\hline & & $s$ & & & $Z$ & $P$ \\
\hline Dışa Yönelim (DY) & 13,75 & 1,70 & 18,66 & 9,50 & $-1,06$ & 0,28 \\
\hline İçe Yönelim (İY) & 7,75 & 3,30 & 13,33 & 7,37 & $-1,06$ & 0,28 \\
\hline Davranış Problemleri Ölçeği Toplam & 21,50 & 3,10 & 32,00 & 15,87 & $-1,06$ & 0,28 \\
\hline
\end{tabular}

Tablo 6. Deney ve kontrol grubundaki çocukların problem davranış ölçeği alt boyutlarına ilişkin erişi puanlarına ait U-testi sonuçları

\begin{tabular}{lcccccc}
$\begin{array}{l}\text { Problem Davranış Ölçeği } \\
\text { N=8 }\end{array}$ & \multicolumn{2}{c}{$\begin{array}{c}\text { Deney } \\
\boldsymbol{n = 4}\end{array}$} & \multicolumn{2}{c}{$\begin{array}{c}\text { Kontrol } \\
\boldsymbol{n}=\mathbf{4}\end{array}$} \\
\hline & Sıra Ort. & Sıra Toplamı & Sıra Ort. & Sıra Toplamı & $\boldsymbol{U}$ & $\boldsymbol{p}$ \\
\hline Dışa Yönelim (DY) & 2,50 & 10,00 & 6,50 & 26,00 & 0,00 & 0,02 \\
İçe Yönelim (iY) & 3,25 & 13,00 & 5,75 & 23,00 & 3,00 & 0,02 \\
Davranış Problemleri Ölçeği Toplam & 3,00 & 12,00 & 6,00 & 24,00 & 2,00 & 0,08 \\
\hline${ }^{*} \mathrm{p}<0,05$ & & & & & &
\end{tabular}


terapisini kullanmayı desteklemektedir (27). İçe yönelim problem davranışları alt boyutu deney ve kontrol grubunda bulunan çocukların son test puan ortalamalarında ve ön test-son test puan ortalamaları arasında anlamlı fark olmadığı gözlenirken, deney grubundaki çocukların son test puanlarındaki ivmeli düşüş deneysel işlemin içe yönelim problem davranışları azaltması şeklinde yorumlanabilir. Deney grubundaki çocukların problem davranışlarındaki son test izleme testi puan ortalamaları arasındaki farkın anlamlı olmaması oyun terapisinin dikkat eksikliği hiperaktivite bozukluğu belirtili çocukların duygu ve davranışları üzerindeki etkisini inceleyen Zorlu (2016)'nun çalışması ile benzer bir sonuç göstermektedir. Yönlendirici olmayan oyun terapisinin dikkat eksikliği hiperaktivite bozukluğu belirtili çocukların duygu ve davranışları üzerindeki etkisinin incelendiği araştırma sonucunda son test ile izleme testleri arasında ise anlamlı fark görülmemesinin uygulanan yönlendirici olmayan oyun terapi müdahalesinin deney grubundaki dikkat eksikliği hiperaktivite bozukluğu belirtili çocukların duygu ve davranışları üzerinde olumlu etkisinin olduğu ve bu etkinin devam ettiği sonucuna varılmıştır (15). Oyun terapisi ile bütünleştirilmiş grup terapisinin çocuklar üzerindeki utangaçlık düzeylerine etkisinin incelendiği araştırma sonuçlarına göre çocukların grup oyun terapisi almadan öncesi ve sonrasındaki utangaçlık düzeylerinde anlamlı bir farklılık olmuş ve 38,84 oranında düşüş göstermiştir (28). Oyun terapisinin uygulandığı birçok araştırma sonuçları çalışma bulgularımızla benzer özellik taşımaktadır (29-31). Araştırmada uygulanan oyun terapisinin çocukların dışa yönelim ve içe yönelim problem davranışlarında azalma oluşturduğu görülmüştür.

\section{Sonuç ve öneriler}

Oyun terapisinin kadın konukevlerinde kalan üç-altı yaş grubu çocukların problem davranışları üzerinde etkisinin olup olmadığını belirlemek amacıyla gerçekleştirilen araştırmanın sonuçları incelendiğinde:

Araştırma kapsamına alınan deney ve kontrol grubu çocukların birbirine yaş ve gelişim, davranış problemleri açısından benzer özelliklere sahip olduğu ve grupların homojen olduğu görülmüştür. Annelerin çocuk ile ilgili verdikleri bilgiler çerçevesinde deney grubunda bulunan annelerin $\% 100$ 'ü, kontrol grubundaki annelerin $\% 75^{\prime} \mathrm{i}$ eşinden şiddet gördüğünü belirtmişlerdir. Bu kadınlardan deney grubunda $\% 100^{\prime} u ̈$, kontrol grubunda ise $\% 75^{\prime} \mathrm{i}$ çocuğunun bu şiddette tanık olduğunu ifade etmişlerdir.

Araştırma kapsamında oyun terapisine katılan çocukların davranış problemlerinin kontrol grubuna göre daha fazla oranda azaldığı, çocukların saldırgan ve düşüncesiz aşırı hareketlilik gibi dışa yönelim problem davranışlarının azaldığı ve çocukların korku, endişe, çekingenlik gibi içe yönelim problem davranışlarının da azaldığı belirlenmiştir. Deneysel işlem sonrasındaki bu olumlu değişiklikler, oyun terapisinin üç-altı yaş grubu çocukların problem davranışları üzerindeki etkisini göstermektedir. Literatürde belirtildiği üzere kadın sığınma evinde bulunan çocukların şiddete tanıklık oranı ve maruz kaldıkları olumsuzluklar nedeniyle meydana gelebilecek problem davranışların önünü alma açısından yapılacak çalışmalar önemlidir.

Araştırma tamamlandığında uygulamanın yapıldığı kurumun il genel müdürlüğü tarafından kadın konukevlerinin tüm şubelerinde görev yapan alan uzmanlarının oyun terapisi eğitimi alarak oyun terapilerinin uygulanmasına karar verilmiştir.

Araştırma sonucunda elde edilen bulgular doğrultusunda geliştirilen öneriler:

- Kadın konukevlerinde bulunan çocuk gelişim alanında rehberlik eden uzmanların oyun terapisi ile ilgili eğitim almaları ve kurumda kalan çocukları destekleyici oyun terapi müdahalelerinin yararlı olacağı düşünülmektedir.

- Bu araştırmada uygulanan oyun terapisi okul öncesi yaş grubu ile sınırlı tutulmuştur. Sonraki çalışmalarda daha farklı yaş grupları ile çalışııması daha fazla kişiye ulaşması açısından faydalı olacaktır.

- Araştırmada genel olarak ele alınan problem davranışlar uzmanlar tarafından çocukların gelişimleri değerlendirilip iyileştirilmesi gereken davranışa göre uygulanması problemlerdeki etkisini arttırmada faydalı olacaktır.

- Oyun terapisinin etkisini arttıran faktörler olarak, seans sayısı arttırılmalı ve annelerin de katılımı sağlanmalıdır.

- Çocukların doğal bir ihtiyacı olan oyuna ve oyun mekânlarına kurumlarda daha fazla yer verilmelidir. 


\section{Kaynaklar}

1. Aral N, Kandır A, Can Yaşar M. Okul Öncesi Eğitim ve Okul Öncesi Eğitim Programı (Geliştirilmiş 2. Baskı). İstanbul:Ya-Pa Yayınları; 2002.

2. Schweinhart LJ, Weikart DP. Young children grow up: The effects of the Perry Preschool Program on Youths Through Age 15 (Monographs of the High and Scope Educational Research Foundation 7). Ipsilanti, Ml. High/Scope Press; 1980.

3. Berrueta-Clement JR, Schweinhart LJ, Barnet WS, Epstain AS, Weikart DP. Changed Lives: The Effects of the Perry Pre-school Program on Youths through Age 19. Ipsilanti: High Scope Press; 1984.

4. Ladd GW. The fourth R. relationships as risks and resources following children transition to school, American Educational Research Association Division E Newsletter 2000;19:9-11.

5. Şehirli N. Çocuk Davranışlarını Değerlendirme Ölçeği'nin Geliştirilmesi ve Bazı Değişkenlere Göre İncelenmesi, Eğitim Bilimleri Enstitüsü, Çocuk Gelişimi ve Eğitimi Anabilim Dalı, Yüksek Lisans Tezi, Gazi Üniversitesi, 2007.

6. Lee $\mathrm{KH}$, Baillargeon RH, Vermunt JK, Wu H, Tremblay RE. Age Differences in The Prevalence of Physical Aggression Among 5-11Year Old Canadian Boys and Girls. Aggress Behav 2007;33:26-37. [CrossRef]

7. Güven E, Erden G. Çocuğun Algıladığı Evlilik Çatışması ve Davranış Sorunları, Sosyal Politika Çalışmaları Derg 2014;32:33-54.

8. Kadim M. Okul Öncesi Öğretmenlerinin Oyun Etkinliklerine İlişkin Öz-Yeterliklerinin Görev Yapılan Okul Türüne Göre İncelenmesi, NEÜ Sosyal Bilimler Enstitüsü Derg 2012;2:1-21.

9. Schaefer CE. Foundations of Play Therapy. Çeviri: Tortamış Özkaya B. Oyun Terapisinin Temelleri, 2. Baskı. Ankara: Nobel Akademik Yayıncılık; 2013. ss.10-53.

10. Özdoğan B. Çocuk ve Oyun, 3. Baskı. Ankara: Anı Yayıncılık; 2000. ss.127-34.

11. Erden G, Altınoğlu Dikmeer İ. Giriş. Içcinde: Ryan V, Wilson K (Çeviri editörleri: Erden G, Altınoğlu Dikmeer I). Case Studies in Nondirective Play Therapy (Yönlendirmesiz Oyun Terapisinde Vaka Çalışmaları), 1. Baskı. Ankara: Nobel Akademik Yayıncılık Ltd.; 2016. ss.1-10.

12. Landreth GL. Play Therapy: The Art of the Relationship, 3. ed. New York: Routledge Taylor \& Francis Group; 2012. p.12.

13. Landreth G, Bratton S. Play Therapy. ERIC Digest. Greensboro, NC: ERIC Clearinghouse on Counseling and Student Services. (ERIC Document Reproduction Service No. ED430172); 1999.

14. Öğretir AD. Oyun ve Oyun Terapisi, Gazi Üniversitesi Endüstriyel Sanatlar Eğitim Fakültesi Derg 2008;22;94-100.

15. Zorlu A. Yönlendirici Olmayan Oyun Terapisinin Dikkat Eksikliği Hiperaktivite Bozukluğu Belirtili Çocukların Duygu ve Davranışları Üzerindeki Etkisinin İncelenmesi, İstanbul, Eğitim Bilimleri Enstitüsü, Eğitim Bilimleri Anabilim Dalı, Yüksek Lisans Tezi, İstanbul Üniversitesi, 2016.

16. İstatistiklerle Çocuk. Statistics on Child 2014. www.tuik.gov.tr/ IcerikGetir.do?istab_id=269 Erişim Tarihi: 13.08.2017.
17. Erbaydar NP. Kadın Sığınmaevleri. http://www.huksam.hacettepe. edu.tr/Turkce/SayfaDosya/siginmaevi_aylikyazi

18. Haj-Yahia MM, Cohen HC. On the Lived Experience of Battered Women Residing in Shelters. J Fam Viol 2009;24:95-109. [CrossRef]

19. Sümbüloğlu V, Sümbüloğlu K. Sağlık Bilimlerinde Araştırma Yöntemleri. Ankara: Hatipoğlu Yayıncılık; 2013. s.45.

20. Secher, M. Batı Trakya Örnekleminde Okul Öncesi ve Anaokulu Davranış Ölçeğinin Geçerlilik ve Güvenirlik Çalışması, Sosyal Bilimler Enstitüsü, İlköğretim Anabilim Dalı, Yayınlanmamış Yüksek Lisans Tezi, Trakya Üniversitesi 2014.

21. Özbey S, Alisinanoğlu F. Okul öncesi eğitim kurumuna devam eden 60-72 aylık çocukların problem davranışlarının bazı değişkenlere göre incelenmesi. Uluslararası Sosyal Araştırmalar Derg 2009:2:493-517.

22. Okyay L. Altı Yaş Grubu Çocukların Aile Resimlerinin Sosyo-kültürel Değişkenler ve Davranış Problemleri Açısından Karşılaştııılması, Sosyal Bilimler Enstitüsü, İlköğretim Anabilim Dalı, Yayımlanmamış Yüksek Lisans Tezi, Trakya Üniversitesi 2008.

23. Memetali S. Batı Trakya Örnekleminde Okul Öncesi ve Anaokulu Davranış Ölçeğinin Geçerlilik ve Güvenirlik Çalışması, Sosyal Bilimler Enstitüsü, IIlköğretim Anabilim Dalı, Yüksek lisans tezi, Edirne: Trakya Üniversitesi, 2014.

24. Öztuna D, Elhan AH. Gruplar arası ve grup içi karşılaştırma yöntemleri. 2005. Türk Toraks Derneği. http://www.toraks.org.tr/SunuMerkezi/?s $=262159252 B 2 A 2 D 5 A 3 E 3$ A5B5F242827

25. Teber M. Çocuk Merkezli Oyun Terapisinin Çocuklarda Görülen Davranış Sorunlarının Çözümüne etkisi, İstanbul, Sosyal Bilimler Enstitüsü, Psikoloji Anabilim Dalı, Yüksek Lisans Tezi, Hasan Kalyoncu Üniversitesi, 2015.

26. LeBlanc M, Ritchie M. Predictos of play therapy outcomes. Int J Play Ther 1999;8:19-34. [CrossRef]

27. Landret $\mathrm{GL}$, Kot $\mathrm{S}$, Giordano M. Intensive child centered play therapy with child witnesses of domestic violence. Int J Play Ther 1998;7:1736. [CrossRef]

28. Yıldız C. Oyun Terapisi ile Bütünleştirilmiş Grup Terapisinin Çocuklar Üzerindeki Utangaçlık Düzeylerine Etkisi, İstanbul, Sosyal Bilimler Enstitüsü, Psikoloji Anabilim Dalı, Yüksek Lisans Tezi, Beykent Üniversitesi, 2015.

29. Akman Y. Serbest Oyun, Yapılanmış Oyun ve Model Alma Tekniklerinin Anaokuluna Yeni Başlayan Çocuklarda Görülen Ayrılık Kaygısının Azaltılmasındaki Etkileri, Hacettepe Üniversitesi Eğitim Fakültesi Derg 1988;3:99-104.

30. Salter K, Beamish W, Davies M. The Effects of Child-Centered Play Therapy (CCPT) on the Social and Emotional Growth of Young Australian Children With Autism. Int J Play Ther 2016;25:78-90. [CrossRef]

31. Jackson Y, Rump BD, Ferguson K, Brown A. Group Play Therapy for Young Children Exposed to Major Stressors: Comparison of Quantitative and Qualitative Evaluation Methods. J Child Adolesc Group Ther 1999;9:3-16. [CrossRef] 